\title{
Online Based Learning Management System (LMS) on Student Academic Performance
}

\author{
Firman 1, Muh.Arief Muhsin ${ }^{2}$, Goestina 3 \\ DOI: 10.35445/alishlah.v13i1. 415
}

\begin{tabular}{ll}
\hline Article Info & Abstract \\
\hline Keywords: & The study aims to analyze students' academic performance using a learning \\
LMS & management system (LMS) through the Moodle feature serving as an online- \\
Moodle & based learning resource, which aims to build an interactive learning process \\
& between teachers and students. Implementation of LMS able to save time, material \\
& organization and conduct effectively and efficiently. The design of this research is \\
& qualitative. It describes the data that has been obtained from the field and the \\
& literature related to the discussion of the use of online academic-based learning \\
& management systems (LMS). The learning process by utilizing information and \\
& communication technology has been used with effective learning. It can be stated \\
& that the use of e-learning in LMS has functioned as a learning resource, a learning \\
& tool, and a learning system itself. The quality is mainly emphasized in the process, \\
namely the active role of students in learning activities, changing conventional & learning patterns of students only accepting existing information (transfer of \\
knowledge) and active patterns.
\end{tabular}

\begin{abstract}
Abstrak
Kata kunci:

LMS

E-Learning

Moodle

Penelitian ini bertujuan untuk menganalisis kinerja akademik siswa dengan menggunakan learning management system (LMS) melalui fitur Moodle yang berfungsi sebagai sumber belajar berbasis online, yang bertujuan untuk membangun proses pembelajaran yang interaktif antara guru dan siswa. Penerapan LMS mampu menghemat waktu, material organisasi dan pelaksanaannya secara efektif dan efisien. Desain penelitian ini adalah kualitatif. Diuraikan mengenai data yang telah diperoleh dari lapangan dan literatur terkait pembahasan penggunaan sistem manajemen pembelajaran berbasis akademik (LMS) online. Proses pembelajaran dengan memanfaatkan teknologi informasi dan komunikasi telah digunakan dengan pembelajaran yang efektif. Dapat dikatakan bahwa pemanfaatan e-learning dalam LMS telah berfungsi sebagai sumber belajar, sarana pembelajaran, dan sistem pembelajaran itu sendiri. Kualitas lebih ditekankan pada prosesnya, yaitu peran aktif siswa dalam kegiatan pembelajaran, perubahan pola pembelajaran konvensional siswa hanya menerima informasi yang ada (transfer of knowledge) dan pola aktif.
\end{abstract}

\footnotetext{
${ }^{1}$ Universitas Muhammadiyah Makassar, Makassar, Indonesia

Email: firman@unismuh.ac.id

${ }^{2}$ Universitas Muhammadiyah Makassar, Makassar, Indonesia

Email: arief.m@unismuh.ac.id

3 Universitas Negeri Yogyakarta, Yogyakarta, Indonesia

Email: goestinagoes@gmail.com
} 


\section{INTRODUCTION}

The rapid advancement of science and technology has brought many changes in education. Information and communication technology (ICT) (Sriwindono, Tumiwa in Singgih \& Ismail, 2017: 308). ICT in education to facilitate financial management or administration as a learning support process and learning object. E-learning is an effective learning process produced by combining digital material delivery consisting of support and services in learning (Waller, 2001).

The use of e-learning in the current era is more widely used as a learning medium by utilizing digital technology to provide material, syllabus, questions, and discussion forums. Developing an elearning learning system requires training to operate the application first for teachers and students, as a form of habituation of students using technology and presenting a different atmosphere in the teaching and learning process. This way, it is hoped that this way will motivate active and enthusiastic students in receiving the material. The development and existence of internet technology help create choices and alternatives in the teaching and learning process (Dedy, 2010: 258). Meanwhile, according to Rusman in Hanum (2013) e-learning has characteristics, including (a) interactivity(interactivity); (b) independency (independence); (c) accessibility (accessibility); (d) enrichment (enrichment) . In this case, e-learning requires an integrated online learning management system, namely the learning management system (LMS) (Munir, 2010: 110).

Some examples of LMS learning platforms, namely Edmodo, Quipper, and Google Classroom, can be accessed by anyone. Without payment, they function as a learning medium and a learning resource for students (Singgih \& Ismail, 2017: 308). Various facilities that can be obtained from implementing LMS in the teaching process, namely saving time, material organization, and time availability, are carried out effectively and efficiently (Dedy, 2010: 259). Previously have examined the relationship of involvement in the learning model with LMS, face to face, based on the performance of the end learning website (Baragash \& Al-samarraie, 2018).

Ease of accessing LMS for educators and students anytime, anywhere via any device (PC, laptop, or Smartphone). Learning management system is considered very good and in demand among students to university students, because its features are quite complete, starting from chatting, uploading Ms. files. Word, pictures, excel, ppt, video, taking questions and providing value outside of face-to-face learning. Significantly advancing e-learning, educators and students find new ways to increase knowledge, teaching, and experience in the classroom (Sudiana, 2016).

The identification of the e-learning program provides an illustration that so far, many schools have developed e-learning. However, some are complete at a point that is not optimal, some have reached the content development stage, but some are still at the pilot stage or early development. However, schools have a high commitment to the development of learning with e-learning. The problems felt by most schools relate to school management and software development. Problems related to management include that school programs and policies constrain the development of elearning. Therefore, a detailed and in-depth analysis of the application of active learning based on a learning management system is needed. It is hoped that the results of this analysis will be more significant and actively participate in the online learning process through a learning management system. Therefore, this study aims to facilitate access to LMS in e-learning learning for students.

\section{METHODS}

This research is qualitative. Qualitative research procedures produce descriptive data in written or spoken words from people and observable behaviour (Moleong, 2007:4). This qualitative research is generating theory, not hypothesis testing so that this theory is produced in the form of substantive theory and grounded theories (Zuriah, 2006:82). This study describes the data that has been obtained from the field as well as from the literature related to the discussion. In building this information system, data collection is carried out as follows: a) field research, at this stage of research carried out first with field studies at SMU Negeri 1 Bajeng, b) library research, at this stage data collection, is carried out by studying books (literature) on the use of online learning management systems for students at 
SMUN 1 Bajeng Kab. Gowa. The descriptive analysis technique by classifying information from qualitative data in input, feedback, criticism, and suggestions is then used to strengthen the data and revise the product. Descriptive statistical analysis was used to analyze the data by describing the data collected from the development results, validator responses, and student responses in each trial.

\section{FINDINGS AND DISCUSSION}

In general, the procedure for the flow of activities in developing LMS-based learning programs is as follows:

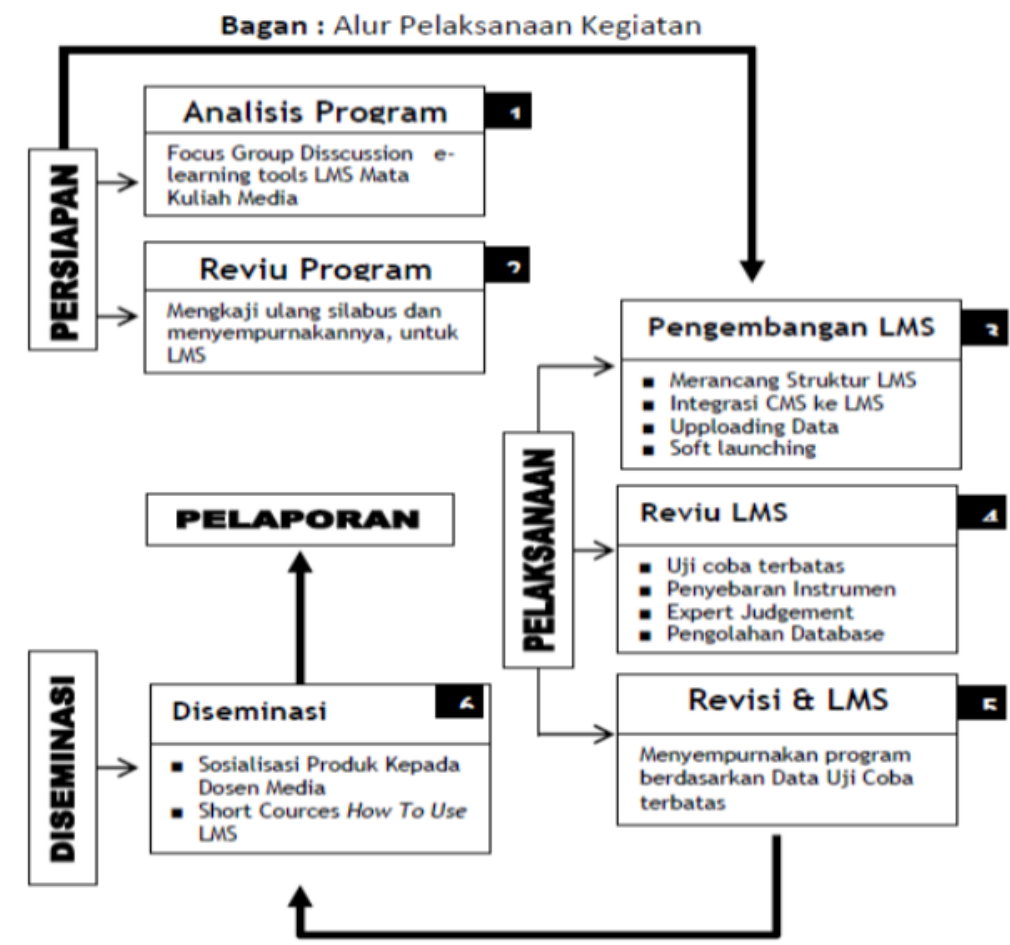

Figure 1. Activity Execution Flow

This activity aims to develop a learning management system (LMS) as a mode of e-learning and in a wider context as a form of ICT application in education. LMS, in this case, serves as a learning resource, a learning tool, and the learning system itself. The quality in question is mainly emphasized in the process, namely the active role of students in learning activities, changing conventional learning patterns, and accepting existing information (transfer of knowledge) and active patterns.

To find out the effectiveness of e-learning supporting software in SMUN 1 Bajeng, it is necessary to compare the real conditions of e-learning supporting software and the requirements of software standards that are under the following ICT developments:

a. Use system software and applications based on Windows, Linux, and the web with consideration of facilitating the operation of an attractive display, compatibility with hardware, data transfer speed, and compatibility with developments in information technology.

b. Use a good security system, such as firewalls, passwords, and web-based software for a wider range of systems.

c. All information in the e-learning system must be updated frequently, for example, two times a week.

The stages of developing a learning management system (LMS) as a learning medium are:

a. Define: That stage is curriculum analysis and student analysis.

b. Design: The stage is the design of the learning management system as a learning medium.

c. Develop: It is in the form of validation and practicality tests on the learning management system (LMS) as a learning tool,

d. The dissemination stage is in the form of the LMS dissemination stage as a learning medium. 
In the activity, the program has been made in the form of an LMS (Learning Management System) with the following characteristics:

a. Content, which contains varied media with Multimedia format. Such as text, images, video, animation, and audio (sound). In addition, the available files are not only in the form of documents and PDFs but can be mov/avi/mpg/gif/jpg, etc.

b. Activities, teachers and students can access widely, can upload at any time and vice versa. Learning activities can occur directly and will be recorded in the database as input for the teacher's assessment.

c. Updating that can be done by teachers and students anytime and anywhere (anywhere and any time).

d. Communication means the interaction between teachers and students is multi-directional. Interactive communication will occur through discussion forums, video conferences, online quizzes and others.

Based on the results of observations and interviews, it can be described that the condition of human resources supporting computer-based management information systems at SMU 1 Negeri Bajeng can be grouped as follows:

a. School IT managers, in most schools, are ICT teachers as well as those responsible for leading the data processing unit and developing information systems in schools, including e-learning. In some schools, this task is held by the school admin.

b. Systems analyst are experts who are responsible for the development of computer-based information systems.

c. Programmers are experts who are responsible for compiling programs to operate on computers.

d. The database manager is the person who creates the database in several schools.

e. Network specialists consist of people who are responsible for the installation, maintenance and repair of the network. For network specialists, it is carried out by technicians in each SMUN 1 Bajeng.

f. There are computer operators in every section and section at SMUN 1 Bajeng.

g. Data providers are usually carried out jointly or in collaboration between employees on their respective parts.

The results of the identification of the e-learning program at SMUN 1 Bajeng provide an illustration that e-learning has developed. However, it is not yet maximized. Some can be said to be complete, some have reached the stage of content development, but some are still at the pilot or early development. However, schools have a high commitment to the development of learning with elearning. The problems felt by most schools relate to school management and software development. Problems related to management include that school programs and policies constrain the development of e-learning. Concerning software, schools have developed their e-learning using Moodle software. However, the plug-ins are not yet complete (e.g. plug-ins (dragMath) for equation facilitation), so they will follow those developed by the Research Team. In addition, there is a problem with hosting - if it comes out, the capacity is limited; if the facilities are also limited. Another problem relates to software maintenance and course content developed through e-learning. Thus, e-learning at SMU 1 Negeri Bajeng needs to be further developed to be effective for improving the education and learning system. It is in line with Singgih (2017) statements that a learning management system (LMS) is a platform or application for online learning activities or can be called virtual classroom learning, while the platform's contents are by design and some are by utilization.

SMUN 1 Bajeng through the Computer Center in optimizing the use of information technology to support learning activities is manifested through the development of an integrated Information and Communication Technology (ICT)-based learning system. The ICT-based learning system allows teachers to manage content more easily and flexibly while carrying out learning management functions. A Learning Management System (LMS)/Virtual Learning Environment (VLE) learning management system called Moodle in a web application to create effective online learning has been introduced.

Page 791 of 793 
Through Moodle, teachers can manage the subject matter from compiling syllabus, uploading material, giving assignments/assignments, receiving and responding to student work, making quizzes or tests, conducting assessments, monitoring student participation, and interacting with fellow teachers and students. It can be implemented on scientific forums and online discussions. Agung et al. (2014) state that E-learning can train students' independence in technical and experience. It can also help educators monitor the activity of students doing the assigned tasks, discussion forums and other activities so that the character of students can be described through the concept of e-learning.

Based on the different characteristics of software communication and resources for e-learning, there are three basic categories in e-learning; self-study means that participants in the learning process do not interact, or learning activities are not limited by time. The independent learning approach aims at tools and materials that are prepared in advance that students use without direct interaction (Allesi \& Trollip in Nur, Rudy \& Hafiz, 2020:107); asynchronous means the e-learning learning process is facilitated by tools that do not require participants to be present at the same time (B. Holmes \& J. Gardner, 2006); synchronous means a learning process that requires participants to take part in virtual simultaneously or live, because of the real-time character of Synchronous e-learning (J.C. Granda, 2010).

Moodle provides five types of subject matter which are static. Students can read the subject matter. However, it cannot interact with text pages, Html pages, links with web viewing directories and display labels in the form of text or images. In addition to making the teaching and learning process more interactive, Moodle provides various activities: Assignments, Choices, Lessons, Quizzes, Surveys, and Journals. Moodle also provides five types of features for student-to-student and student-teacher interaction activities.

The application of the Moodle feature at SMUN 1 Bajeng is still at the planning stage. These initial activities include:

a. Establish competency standards developed and determined based on content standards and subject syllabus at SMUN 1 Bajeng.

b. Choose basic competencies in topic coverage that allows students to learn and benefit from using e-learning.

c. Identify the characteristics of students based on the results of tests carried out by students.

d. Supporting resources to collect sources or references can be used as a reference in developing elearning using Moodle.

e. Conduct discussions with subject teachers and peers as expert judgment regarding the content to be developed in e-learning. The development steps include a) making e-learning instructions, materials, presentation materials, exercises and assignments. b) Moodle installation, and c) Moodle configuration.

The Learning management system (LMS) used for education in Indonesia is Moodle, which provides complete features for creating and managing to learn, checking student attendance and performance, quizzes, assignments and surveys. Moodle is designed so that universities, schools, businesses, and even individual instructors have started to take advantage of the advantages of this web technology as a traditional substitute for today's classrooms. Moodle is designed to support a learning style called Social Constructionist Pedagogy which is interactive.

\section{CONCLUSION}

The results of the identification of e-learning programs in schools illustrate that the use of the Learning management system (LMS) on the Moodle feature for student academic performance at SMUN 1 Bajeng has not reached its maximum point. In this case, there is still a need for a content development stage in managing the system. For the effectiveness of e-learning supporting software in SMUN 1 Bajeng environment, it is necessary to compare the actual conditions of e-learning supporting software and the requirements of software standards according to the development of Information and Computer Technology. 


\section{REFERENCES}

Agung. T.W., Isa. \& Sunyoto. E.N., (2014). Pengembangan LSM (Learning Management System) Berbasis Web untuk Mengukur Pemahaman Konsep dan Karakter Siswa. Scientific Journal of Informatics. Vol. 1(2)

Baragash, R.s., \& Al-Samarraie, H. (2018). Blended learning: Investigating the influence of engagement in multiple learning delivery modes on students' performance. Telematics and Informatics. Doi: 10.1016/j.tele.2018.07.010.

B. Holmes, \& J. Gardner. (2006). E. Learning: Concept and Practice. London: sage Publications.

Clark, R.C. \& Mayer, R.E (2008). E-learning and the science of instruction: proven guidelines for consumers and designers of multimedia learning, second edition. San Francisco: John Wiley \& Sons, Inc

Dedy, S. 2010. Pemanfaatan Learning Management System (LMS) pada Mata kuliah software Quality Assurance. Jurnal sistem Informasi (JSI). Vol. 2(2)

Irsan, T.A. (2011). Analisis Hubungan Implementasi multimedia pada learning management system terhadap kemampuan mahasiswa dalam penguasaan materi pembelajaran. Jurnal Sains dan teknologi. Vol. 10(1).

J.C Granda, et, all. (2010). An Efficient Networking Technique for Synchronous E-learning platforms in corporate Environments. Computer Communication. Vol. 33. 1752-1766

Kridanto, S., (2005). Pengembangan Learning Content Management System yang mendukung peningkatan efektifitas proses belajar jarak jauh. Jurnal Teknik elektro. Vol. 5 (1).

Munir. (2006). The effectiveness of Multimedia in Education Package to Motivate literacy (MEL) amongst Preschool Children. Compare I (2). Journal of Comparative Education Society of Asia.

Munir. (2009). Pembelajaran jarak jauh berbasis teknologi informasi dan komunikasi. Bandung: Alfabeta.

Munir. (2010). Penggunaan Learning Management System (LMS) diperguruan tinggi studi kasus Universitas Pendidikan Indonesia. Cakrawala Pendidikan. Vol. 13 (1)

Nur, I., Rudy D, N., \& Hafiz, M. (2020). Aplikasi Learning Management System pada Jenjang Madrasah Aliyah. Jurnal system dan teknologi Informasi. Vol. 8(1).

Novi. M., \& ahmad. F., (2019). Pemanfaatan Learning Management system dalam proses pembelajaran Matematika Diskrit. JET-MAT, Vo. 5(1)

Siahaan, S. E-learning (pembelajaran Elektronik) sebagai salah satu Alternatif kegiatan Pembelajaran. http://www.depdiknas.go.id. Diakses tanggal 28 Maret 2020

Singgih, I., (2017). Dampak Learning Management system (LMS) Pada performa Akademik mahasiswa di perguruan Tinggi. Jurnal Pendidikan dan Pembelajaran. Vol. 2 (4).

Sudiana, R. (2016). Efektifitas Penggunaan learning management system berbasis Online, 9 (2), 201209.

Setya, R, Lantip, D. P., \& Ariyawan. A. N., (2011). Model Pembelajaran Berbasis Learning Management system dengan pengembangan software moodle di sekolah menengah Ats. Jurnal Kependidikan. Vol. 41 (1)

Vaughan, Tay., (2004). Multimedia: making Work sixth Edition. New Work: Mc Graw-Hill Companies, Inc.

Hardjito. (2002). Internet untuk pemnelajaran, Jurnal Teknodik. 10, 23-45.

Racw, W. H., \& Nash S.S. (2010). Moodle 1.9 teaching techniques: Creative ways to build powerful and effective online course. Birmingham: PACKT Publishing.

Lexy, J., M. (2007). Metedologi Penelitian Kualitatif, Bandung: Remaja Rosdakarya.

Waller, Vaugan, \& Wilson. (2001). A definition for e-learning in newsletter of open and distance learning quality control. Sumber dari internet: http://odlqc.org. uk/odlqc/n19-e.html, diakses 23 februai 2021.

Zuriah. N., (2006). Metedologo penelitian social dan Pendidikan, Jakarta: Bumi Aksara. 